\title{
Corporate Governance, Regulatory Agency and Creative Accounting Practices in Nigeria
}

\author{
Odia, J.O. (PhD) \\ Department of Accounting, University of Benin, \\ Benin City, Nigeria \\ odiajames@yahoo.com.234-8056580011 \\ Ogiedu, K.O. (PhD) \\ Department of Accounting, University of Benin, \\ Benin City, Nigeria \\ koogiedu@yahoo.com 234-8033600045
}

\section{Doi:10.5901/mjss.2013.v4n3p55}

\begin{abstract}
This paper deals with the impact of corporate governance and the regulatory activities of Nigerian Accounting Standards Boards (NASB) on creative accounting practices in Nigeria. A survey of the key players involved in financial reporting in Nigeria reveals that creative accounting practices exists in Nigeria. Using the linear regression analysis, it was found that both the corporate governance structure and the NASB's monitoring and enforcement of accounting standards have had insignificantly negative impact on creative accounting practices. Nevertheless the corporate governance tends to militate against creative accounting practices more than the policing by NASB. Therefore, it is recommended that the corporate governance mechanisms should be strengthened and the NASB should devise appropriate means and enlightenment, in addition to the sanctions and fines, for the elimination of creative accounting practices in Nigeria.
\end{abstract}

Keywords: Creative accounting, corporate governance, Nigerian Accounting Standards Board.

\section{Preamble}

Since the Enron's debacle of 2001 and the recent global financial meltdown, there have been a lot of corporate frauds and scandals, manipulations and consequent collapses of many corporations globally due to Creative Accounting practices. These practices were perpetuated by management and staffs in connivance with the auditors. The Nigerian Corporate world witnessed alarming distresses in the banking sectors in the 1990s owing to the sharp practices prevalent in the industry. The collapse of Savanna Bank and African International Bank (AIB), overstatement of Cadbury's account between N13 billion to N15 billion over a number of years, accounts manipulation in Africa Petroleum (AP) and the sack of five chief executive officers of Nigerian banks by the Central Bank of Nigeria have been linked to Creative Accounting practices.

Usually corporate financial statement is the tool for reporting and communicating financial performance, position and change in financial position of an enterprise. This enables users to make informed economic decision. However, financial statement could be manipulated when the accounting guidelines, regulations and rules are downplayed to suit the various purposes of management and directors or when there is weak internal control, poor corporate governance structure, and weak regulatory and monitoring mechanisms. Where the evaluation of the manager's performance has been linked to indices in the financial statement or stock value appreciation, there have been indications of Creative Accounting practices (Gillespine \& Lewis 2000; Healy, 1985).Various definitions have been given on Creative Accounting.

For instance, Schipper (1989) observes that 'Creative Accounting' can be equated with 'disclosure management', in the sense of a purposeful intervention in the financial reporting processes. In Naser (1993) view, "Creative Accounting is the transformation of financial accounting figures from what they actually are to what preparers' desire by taking advantage of the existing rules and/or ignoring some or all of them".

According to Osaze (1998), Creative Accounting refers to the manipulation of normal accounting and financial statements by moving accounts around, changing their locations and sub-heads, re-defining accounting and even 
inflating accounts in order to present an unattractive picture of the state of health of an organization or a rosier one, depending on the objective being pursued. Okoye \& Alao (2008) defined Creative Accounting as an "accounting practices that tend to circumvent, albeit, cleverly, or manipulate the rules of standard accounting practices or the spirit of those values. They are characterized by dubious complication and use of 'novel' ways of presenting income, assets or liabilities". Vladu \& Matis (2010) define Creative Accounting as a mean being used by the company in order to adapt, develop and become more competitive in the turbulent environments in which they operate, adaptation that requires highly adaptive professionals able to generate creative ideas even if these employ interpreting grey areas to their advantage being less prudent almost all the time; seek for loopholes in specific rules being not as consistent as should be or develop devices which regulators have not thought to forbid. ". It is a deliberate dampening or frustration in firm's earnings by talking advantages of loopholes in accounting rules, or using accounting choices, estimates, principles and practices allowed by accounting regulation (Alexander \& Archer, 2003; Nelson el al, 2002, Griffin, 1986)

Corporate governance is the means by which minority shareholders are protected from expropriation by managers or controlling shareholders. Corporate governance is concerned with the way in which stakeholders in a firm attempt to ensure managers and other insiders take measures or adopt mechanisms which safeguard their interests. Good corporate governance provides incentives for both board and the management to pursue objectives that are in the interest of the company and the stakeholders. It helps in improving economic efficiency and incorporates a set of relationship between a company's management, board, shareholders and other stakeholders (Oladimeji,2003). It ensures companies are well run to garner confidence of investors. It safeguards against corruption, mismanagement, corporate wrongdoings and frauds and promote effective risk management, transparency, accountability and firm's performance (Adedipe, 2004, Okeahalam \& Akinboade,2003). Corporate governance involves the sets of processes, customs, policies, laws, mechanisms and institutions affecting the way a corporate entity is directed, administered or controlled (OECD, 2004)

A company is usually fraught with many conflicts of interest: firstly, between professional managers and shareholders, but also between shareholders and bankers and even between shareholders themselves (majority/minority shareholders). Effective corporate governance practices are one of the ways in which conflicts of this kind could be resolved. The aim of such practices is to protect the interests of shareholders by monitoring management more closely, either directly, by specifically reserving a certain number of powers for the General Meeting of shareholders, or indirectly, through a board of directors intended to represent shareholders' interests.

Creative Accounting manifests through window dressing, income smoothing ,balance sheet manipulation, aggressive accounting or account manipulation, earnings management arising from changes in accounting policies or methods, capitalization of cost, ownership structure, cash flows, leasing and securitization transactions, "big bath" restructuring charges, creative acquisition accounting or wrong use of materiality concept to justify error.

Creative Accounting involves a lot of ethical issues because the personal integrity, morality, sense of judgment, belief, training and discipline of the account preparers play a significant role. (Liandu,2004; Elliot \& Elliot,2004; Merchant \& Rolkiness,1994; Fisher \& Rosenzweigh,1995). Creative Accounting irregularities and corporate financial reporting failures have been perpetuated by corporate organizations with many unnoticed and covered up until the bubble burst in the Enron's and other corporate collapses in the United States. These corporate scandals and failures have their roots in dishonest management decision and, in some cases, outright cover-ups of illicit activities. Similarly, they had enormous implications which shook the global economic and corporate environment.

In fact, the collapse of Enron and WorldCom and their multiplier effects brought the accounting profession under sharp scrutiny by a disturbed and bewildered public, questioning the competence and integrity of accountants and accounting profession. It casts doubts on the extant standards of corporate governance. Now, extra demands are being made on the auditors, audit committee, management and accounting firm to guarantee the "true and fair view" of the financial statement in order to protect the investors and the public.

In response to the call for accounting reform to save the economy and accounting profession the United States Government signed into law the Sarbanes Oxley (SOX) Acts of 2002.The SOX created new roles of financial reporting for the auditors, management and the audit committee. Unfortunately, five years later in 2007, the global financial crisis besieged the US and the rest of the world despite the SOX.

\subsection{Statement of Research Problem}

The manipulations of financial statements and subsequent corporate collapses are currently recurring phenomena globally. Various countries have tried to address this situation in order to guarantee the credibility of the financial 
statements through ensuring strong corporate mechanisms and strict compliance with accounting standards. Since the 1990s, the Nigerian corporate world has been beset bank distresses, corporate frauds and collapses in various dimensions. Due to the growing concerns and need to align practices in Nigeria to international best practices, the Peterside's Code of corporate governance in Nigeria was released in 2003 for public companies. The Central Bank of Nigeria released the code of best practice on corporate governance for banks in the post-consolidation era in 2006. Although the Nigerian Accounting Standards Board (NASB) was established in 1982, the organization was given the legal backing in 2003 to issue, monitor and ensure compliance with the accounting standards. This study investigates whether the corporate governance mechanisms and the enforcement activities of the NASB have significant impact on Creative Accounting practices in Nigeria. The research questions are:

1. Is there a relationship between corporate governance and Creative Accounting practices?

2. What is the role of regulatory agency like the NASB in curbing creative accounting practices in Nigeria?

\subsection{Objectives of the Study}

The objective of this study is to examine whether creative accounting practices is manifested in the corporate financial reporting in Nigeria. Thus, the study seeks to:

1. Ascertain whether corporate governance structure affects Creative Accounting practices

2. Determine the role of regulatory agency like the NASB in creative accounting practices in Nigeria

\subsection{Hypotheses}

Two main hypotheses are employed to encapsulate the essence of this study.

1. There is a significant inverse relationship between the corporate governance structure and the rate of Creative Accounting Practices in Nigeria.

2. The policing of companies by the NASB will decrease the creative accounting practices in Nigeria.

\section{Literature Review}

\subsection{The double -edged of Creative Accounting Practices}

The concept "creative accounting" is examined under two important viewpoints: a positive one and a negative one. From a positive viewpoint, it may seem that creative accounting connotes invention of accounting principles and techniques to recognize changes in economic, social, political and also business environments and recognizes genuine changes in accounting practice. From a negative viewpoint, creative accounting means undesirable practices which assimilates unethical elements for attracting providers of the capital by presenting an misleading and deceptive state of a certain firm`s affairs (Vladu \& Matis ,2010). Generally, creative accounting is badly treated, as a negative creation, designed to prepare the financial statements in order to respond managers' requirements regarding the company's financial position and performance. Therefore, the financial statements are rather misrepresentation of the company's performance than true reporting. The negative treatment of creative accounting does not exclude the positive one. Griffin (1995) says there is a very thin and frail line between creative accounting and fraud.

\subsection{Reasons for Creative Accounting Practices}

Schipper (1989) considers the information perspective as underpinning creative accounting phenomenon. This is because accounting disclosures have information content that possess value to stakeholders providing useful signals. Managers may choose to exploit their privileged positions for private gain due to information asymmetry. The conventional accounting model presents opportunities for managers to manipulate the profit figure (Gillespine \& Lewis 2000). Again Davidson (2002) argues that the complex business environment, increasing pressures on companies during economic turbulence often make managers to improve the bottom-line figure. These pressures which could be situational (on company and the managers), unrealistic budget pressure or financial pressure (AICPA, 1987) have driven management to flex the accounting number (Levitt, 1997). The pressures could also be market expectations, personal 
realization of a bonus or maintenance of position within a group of companies, or achievement of consensus estimates etc allow questionable accounting practices to obfuscate the financial reporting process.

Creative accounting is said to arise because companies are subject to various forms of contractive rights, obligations and constraints based on accounts or reports. The reasons for creative accounting include: to get increase investors' confidence, ability to report stable earnings and psychological expectations due to changes in anticipated income (Heyworth, 1953), positive effects of income smoothing on expectation, on securities valuation and risk reduction (Healy \& Wahen, 1999), tax motivation (Niskanen \& Keloharju, 2000; Herman \& Inoue, 1996), executive compensation tied to income measurement (Healy, 1985), change in accounting method or due to ways companies designed their accounting policies (Fox, 1997). Sweeney (1994) reports that companies which are near violation of debt covenants are two to three times more likely to make income increasing accounting policy changes than others. Income smoothing has also resulted from management felt-need to neutralize environment uncertainty and dampen the wide fluctuations in the firm's operating performance subject to intermittent cycle of good and bad times (Riahi-Belkaoui, 2000). Spohr (2004) argued that given the public firm's clearer separation of ownership and management, the strongest identified motives for income smoothing was bonus plan and job security motives. Institutional investment was positively associated with income smoothing (Carlson \& Bathala, 1997). However, Dey (2004) found that firms with higher analysts following and investment smooth income less. Firms also smoothed income due to bonus compensation (Moses, 1987), Job security (Defone \& Park, 1998) capital market reasons (Dechow \& Skinner, 2000).

Sutton (2000) gave reasons why managers manipulate accounting numbers to include: reduction in tax and regulatory burden, raise capital more cheaply, avoid violation of debts contracts and increase manager's wealth. Gramlich, et al (2001) suggested that firms may engage in balance sheet manipulation to reclassify liabilities in order to smooth reported liquidity and leverage ratios. Black et al (1998) examine non-current asset to sales as a tool for Creative Accounting. They found that where relevant accounting standards are permissive, managers will exploit the potentials for Creative Accounting via timing of assets sales. Hillier \& McCrae (1998) provide evidence that depreciation is used to either increase or decrease profits as required by management. Idialu (2004) reported that a wide range of depreciation rates was used by companies in Nigeria contrary to the SAS 9 on depreciation. He found the ranges for freehold and leasehold land and building to be 1-5\%; and lease life plant and machinery (5-25\%), Motor vehicles (4-50\%), Equipment (10-20\%) and lease term furniture (4-33.3\%). Amat et al (2003) found Creative Accounting practices in 35 large Spanish listed companies were relatively overt and almost certainly legal. Odia (2005) finds that creative accounting practices existed in the corporate financial reporting in Nigeria due to the corrupt environment, flexibility in the local GAAP, poor training of accountants and professional code of conduct. He also found managers under pressures manipulate the financial reports

\subsection{Consequences of Creative Accounting}

The practice of creative accounting has the power to distort the underlying financial performance of a firm, making more difficult for an investor or financial analyst to assess the performance of the firm and to compare between different companies. Creative Accounting practices underlie most corporate frauds and accounting scandals (see table 1). It may be difficult or completely impossible for individual stakeholders to notice the effect of accounting manipulations because of inefficient personal skill, indifference or unwillingness to engage in detailed analysis. Even analyst's perception of Creative Accounting devices is somewhat deficient (Breton \& Taffler, 1995). They argued that even the sophisticated users can misinterpret or even ignore such clear signals. Therefore, Dechow \& Skinner (2000) argued that even if financial statements provide sufficient information to permit users to adjust for Creative Accounting, there would still be cause for concern over the value of the information content. This is because of the possibility that certain investors rely completely in earnings numbers reported in the face of the income statement and their ability to process more sophisticated information is limited. Due to Creative Accounting, Schiff (1993:94) has warned the investors who take a company's financial statements at face value can be 'a recipe for disaster'. 
Table 1. Major scandals of the twenty-first century

\begin{tabular}{|c|c|c|c|c|}
\hline & Company & Year & Auditor & Descriptions \\
\hline 1 & Enron & 2001 & Arthur Anderson & $\begin{array}{l}\text { Involved in special purpose entities } \\
\text { transactions }\end{array}$ \\
\hline 2 & Global Crossing & 2002 & Arthur Anderson & $\begin{array}{l}\text { Overstated revenue and earnings above } \\
\text { network capacity swaps. }\end{array}$ \\
\hline 3 & WorldCom & 2002 & Arthur Anderson & $\begin{array}{l}\text { Covering and recording of improper } \\
\text { expenses, Overstated cash flows }\end{array}$ \\
\hline 4 & Tyco & 2002 & $\begin{array}{c}\text { Price Water House } \\
\text { Coopers }\end{array}$ & $\begin{array}{l}\text { Conglomerate with questionable practices on } \\
\text { accounting for actions and other issues. }\end{array}$ \\
\hline 5 & Adelphia & 2002 & Deloitte And Touché & Overstated earnings \\
\hline 6 & Imdone & 2002 & KPMG & Insider trading \\
\hline 7 & Health-South & 2003 & Ernst and Young & Overstated earnings and assets \\
\hline 8 & Fannie Mae & 2004 & KPMG & $\begin{array}{c}\$ 9 \text { billion restatement from derivative } \\
\text { accounting valuations and extent payouts to } \\
\text { ousted executive. }\end{array}$ \\
\hline 9 & Krispy Krene & 2005 & $\begin{array}{c}\text { Price Water House } \\
\text { Coopers } \\
\end{array}$ & Egregious accounting to inflate earnings. \\
\hline 10 & Anglo Irish Bank & 2008 & Ernst \& Young & Hidden loan controversy \\
\hline 11 & $\begin{array}{l}\text { Satyam Computer } \\
\text { Services }\end{array}$ & 2009 & $\begin{array}{c}\text { Price Water House } \\
\text { Coopers }\end{array}$ & Falsified accounts \\
\hline 12 & Lehman Brothers & 2010 & Ernst \& Young & Failure to disclose repo 105 \\
\hline
\end{tabular}

Source: Giroux, G. (2006), Wikipedia (2011)

\subsection{Techniques of creative accounting}

Opportunity for creative accounting practices arises due to: flexibility permitted by the Generally Accepted Accounting Principle (GAAP), imprecise accounting measurement bases, lots of estimations, judgments and predictions, provision for alternative accounting treatment or measurement, artificial and related party transactions, insider dealings, pressure on managers to achieve short-term results, meet budget or raise market share prices and the reclassification and presentation of financial numbers. (Largay, 2002; Mulford \& Comiskey, 2002, Okoye \& Alao 2008).

1. Flexibility in regulation. Generally the regulation, particularly the accounting regulation permits flexibility in choosing a policy to follow; the International Accounting Standards let the financial management to choose between valuation of the non-current assets at depreciated historical value or at revaluated value. The management may decide the change of the policies, and these shifts are difficult to be identified a few years later (Schipper,1989).

2. Lack of regulation is meeting in some areas in every domain. In most countries accounting regulation is limited in some areas, for example in Nigeria there is standards yet for recognition and measurement of financial instruments.

3. Management can use their discretionary position in order to obtain the financial position and stability they assumed; for example, the managers decide to increase or reduce provisions for bad debts (McNichols \& Wilson 1988).

4. The timing of some transactions offers to the management the opportunity to increase the revenues when the operating profit is not satisfactory and to create the desired impression in the accounts. The existing stocks in company's patrimony that have a significant higher value compared to the historical value may be sold only when the operating profit is not satisfactory.

5. The artificial transactions are often used in order to manipulate the balance sheet amounts or to move the profits between accounting periods. These transactions are realized by entering in a controlled transaction with two or three parties, one of them, most of the times, a bank. Such arrangements consists in selling of an asset at a higher/lower rate than in an uncontrolled transaction, and then leasing it back for the rest of it useful period, compensating through the rentals the price difference.

6. Reclassification and presentations of financials are relatively less analysed in accounting literature. However, in reality the companies often proceed to make up the amounts in order to obtain good level of profitability, 
liquidity or leverage ratios. Most of the times, the numbers are smoothly modified in order to improve the investors' perception. As explained by Niskanen \& Keloharju (2000), 'the idea behind this behaviour is that humans may perceive a profit of, say, 301 million as abnormally larger than a profit of 298 million'. Their study and others (e.g. van Caneghem,2002) have indicated that some minor massaging of figures takes place in order to reach significant reference points.

\subsection{Corporate Governance and Creative Accounting}

The conflict of interest among different interest groups or the agency theory represents the real causes of creative accounting (Jensen \& Meckling,1976., Dye ,1988, Christensen \& Feltham (2005). Imhoff (2003) identifies poor corporate governance as responsible for Creative Accounting practices. Earnings manipulation results from diffuse ownership structure (Donnelly \& Lynch (2002). A weak corporate governance structure is more likely associated with misleading accounting information (Giroux,2006) whereas strong corporate governance structure is less prone to fraud, earnings manipulation and other creative accounting practices (Dechow et al,1996, Beasley,1996).Basically, a qualified, committed, independent, tough-minded audit committee represents true guardian of public interest. It monitors management actions and oversees the accounting and financial reporting as well as audit of the company thereby helping to stop earnings management. However, studies by Beasley (1996), Peasnell, et al (2001) and Talib (2003) have found that the presence of audit committee framework in firms has not successfully reduced incidences of earnings management where it lacks independence and ineffective in performing its function. Creative Accounting practices thrive where the auditors act in connivance with managers and where there is strong attachment of auditors to clients (Asein, 2002., Bazermen, Loewenstern \& More (2002)

In corporate governance models, information asymmetry is seen as a genesis point for creative accounting occurrence or earnings management behavior. In a context of information asymmetries, the managers can opportunistically manage the accounting number in order to present the results that are expected by the market. The information perspective and asymmetry have always allowed managers to manage financial reporting disclosures in their favour (Schipper,1989)

Five theories have provided the theoretical underpinning for opportunistic behavior in the area of corporate governance: agency theory; legitimacy theory; institutional theory; signaling theory and stakeholder theory. While agency theory and signaling theory are preoccupied by the investor's informational data regarding financial performance and the channels related to this, the other three theories consider the society as a whole and the stakeholders particular needs of information, is comprised in the audience of firms' disclosures that in those cases offers a different view since in those disclosures social and environmental performances are approached proving the fact that manipulation is not related only to financial performance (Valdu et al, 2010).

\subsection{Corporate Financing Reporting and Regulatory Agencies in Nigeria}

Corporate reporting is regulated in Nigeria by : Companies and Allied Matter Act (CAMA) 2004 (for all registered companies in Nigeria); The Bank and Other Financial Institutions Act (BOFIA) 2006 (for banks and other financial institutions); the Investment and Securities Act (ISA) 1999 (for capital market operations and operators), the Nigerian Accounting Standard Board (NASB) 2003 (issues Statements of Accounting Standards (SASs) for application in the preparation and presentation of financial reports). The NASB Act of 2003 empowers the NASB to enforce and monitor compliance with the SAS. The regulatory framework accords due recognition to corporate financial reporting.The major challenges include: general inconsistencies in the regulations guiding financial reporting and lack of regulatory uniformity and clarity, outdated or no standard at all. Obazee (2005) remarked that because there was no monitoring in Nigeria before passing into law the NASB Act in 2003, many significant accounting and reporting adequacies and departure from norms have passed unnoticed.

\subsection{Creative Accounting Practices and Restatements}

Many of the companies which engaged in the manipulation of their financial statement on discovery are fined and requested to publish restatement. Restatement is an acknowledgement that prior financial statements were not in accordance with GAAP (Palmrose \& Scholz, 2004). It not only indicates financial reporting failure but an admission that previous numbers were false when they were issued. It is a breach in firm's internal control system (Kinney \& McDaniel, 
1989). Wu (2002) reports a loss of confidence in the company's earning following restatements. Restatements have material adverse effect on firms' valuation. In fact, a market reaction of $9.3 \%$ to restatement announcement over a twoday event window was reported by Palmrose et al (2004).Restatement could be technical rather than misstatements arising from routine actions such as discontinued operations etc. Some companies in Nigeria which the NASB has requested to issue restatement include: African Petroleum (AP), Cadbury, Dixon Salt etc. Unilever restated the provisions for unfunded retirement benefit in 2003 as N407.206 mission and not N337.692 million earlier reported. As a way to curb these ugly incidences, the NASB has stipulated stiff penalties and fines for erring companies and their auditors (Odia,2003).

\section{Research Methodology}

The sample population includes the parties concerned with financial statements preparation, usage and regulatory agencies in Nigeria. The survey was carry out in Lagos and Benin City through the administration of a fieldwork questionnaire .The sample was randomly selected from a population made up of : Nigerian Accounting Standards Board (NASB), Central Bank of Nigeria (CBN), Nigerian Stock Exchange (NSE),Corporate Affairs Commission (CAC), Nigerian Deposit Insurance Corporation (NDIC), Federal Inland Revenue Service (FIRS), National Insurance Corporation of Nigeria (NICON), Banks ,Companies accountants, Auditors and Accounting Lecturers and Shareholders (Investors). The categories of respondents include managers of the regulatory agencies and banks, companies managers and accountants, audit partners, accounting lecturers and investors.

The questionnaire follows the likert scale type from strongly agree to disagree and it was closed ended. A total of ninety eight (98) questionnaires were distributed out of which fifty-eight (58) questionnaires was returned. This represented a response rate of $59 \%$. The research instrument was used to collect measurable variables. The questionnaire which contained 44 questions was divided into two sections in order to reflect the areas the study is meant to investigate as follows: A : Creative Accounting, corporate governance and financial reporting Environment in Nigeria (18 questions) Section B: Nigerian Accounting Standards Board (NASB) and financial reporting in Nigeria(8 questions). Section $A$ addressed the issue of corporate governance (auditor and audit committee roles, separation of chairman and CEO position \& ownership structure) affects on Creative Accounting practice. Lastly, Section B assessed NASB's performance and its effectiveness in monitoring and ensuring compliance with the SAS by Nigerian companies. In all the sections, some of the questions were repeated after reframing them to test for consistency in the respondents' responses. The secondary data was used extensively in the literature review. The data was analyzed using percentage analysis, the Pearson correlation coefficient and the ANOVA (F-test). The hypotheses are tested using the regression analysis.

\subsection{Model Specification}

We specify the relationship between Creative Accounting practices (CAP), corporate governance (CGOV) and NASB enforcement and monitoring activities as:

$C A P=\beta+\beta 1 C G O V+\beta 2 N A S B+e$

Where: $\mathrm{CAP}=$ Creative Accounting Practices, $\mathrm{CGOV}=$ Corporate Governance, NASB $=$ NASB's enforcement and Monitoring Activities. $ß 0-\beta 2$ are coefficients, and $\beta 1, \beta 2<0$

\section{Data Analysis}

The statistical tools of analysis consisted of descriptive statistics. The experimental variables examined are Creative Accounting practices, corporate governance and NASB enforcement and monitoring activities using five-point scale. The responses were coded and mapped into numeric values, ranging from (1) Strongly Agree, (2) Agree, (3) Don't Know (4) Disagree to ( 5 ) Strongly Disagree. Correlation analysis was carried out to determine the relationships between Creative Accounting practices (CAP) level and corporate governance Structure (CGOV) on the one hand, and between CAP level and NASB's enforcement and monitoring (NASB) on the other hand. Regression analysis was used to show the impact of the independent variables on the level of Creative Accounting practices. The ANOVA test whether there was no significant difference in the respondents' views that improved corporate governance and NASB's enforcing will reduce Creative Accounting practices in Nigeria. The Statistical Package for Social Sciences (SPSS 15.0) was employed in computing the Pearson's coefficients, ANOVA (F-test) and the regression analysis. The correlation coefficient denotes 
the strength of the relationship on a scale, ranging from -1 to +1 . A positive value close to +1 indicates a strong positive relationship and vice versa. The level of significance for the tests is $5 \%$.

\subsection{Discussions of Responses}

As shown in Tables 2 and 3 below, the mean values of CAP, CGOV and NASB Levels are 2.98, 2.95 and 3.11 respectively. With a mean response of 2.98 and standard deviation of 0.50 , the impact on Creative Accounting practice by the CGOV and NASB is close. However, the mean response of CGOV is less than the mean responses of CAP and NASB. The Pearson correlation coefficient for CAP and CGOV is -0.390 while for CAP and NASB is 0.0089 . Both CGOV and NASB are insignificant at the $0.05 \%$ level. But the result shows that while CAP has a positively weak correlation with NASB, CAP is negatively correlated with CGOV. The interpretation is that the corporate governance tends to have mitigated creative accounting practices unlike NASB's enforcement activities.

Table 2. Descriptive Statistics

\begin{tabular}{|c|c|c|c|}
\hline Variables & CAP & CGOV & NASB \\
\hline Mean & 2.98180 & 2.95785 & 3.11207 \\
\hline Standard deviation & 0.501012 & 0.398387 & 0.395211 \\
\hline $\mathrm{N}$ & 18 & 18 & 18 \\
\hline
\end{tabular}

Table 3. Pearson Correlations

*Significant at $11 \%$.

\begin{tabular}{|c|c|c|c|}
\hline & CAP & CGOV & NASB \\
\hline CAP & 1.000 & & \\
\hline CGOV & $-0.390^{\star}$ & 1.000 & \\
\hline NASB & 0.089 & 0.079 & 1.000 \\
\hline
\end{tabular}

Where: $\mathrm{CA}=$ Creative Accounting Practices, $\mathrm{CGOV}=$ Corporate Governance Structure, NASB $=$ NASB's enforcement and monitoring

\subsection{Corporate Governance Structure and Creative Accounting Practices}

From our investigations, $70 \%$ of our respondents are of the opinion that corporate governance structure affects Creative Accounting practices in Nigeria. The rate of disagreement by the total respondents of $11 \%$ is small compare to the support. Also, there is some support (about $48 \%$ of respondents) that managers in Nigerian companies engage in Creative Accounting practices. Although, almost the same proportion of respondents (35\%) express a contrary opinion.

About $47 \%$ of the total respondents believe managers under pressure manipulate their financial statements. The pressures, which may be due to situational pressures on company and managers, unrealistic budget pressure and financial pressures, drive management to flex the numbers as practicable to achieve their desired aims. Also, companies whose owners (chairmen) were also the CEO, CFO, or MD are believed to engage more in Creative Accounting practices unlike those whose the owners (chairmen) and the CEO, CFO or MD are separated positions occupied by different persons. Our investigation shows $33 \%$ of our total respondents believe the auditors and audit committees do not engage in creative accounting practices but they help to reduce the incidence of the practices in Nigerian companies. On the other hand, $42 \%$ of the total respondents are of the opinion that they engage in creative accounting practices.

The ANOVA result in table 4 shows that there is no significant difference between the various categories of respondents on the impact of a CGOV and NASB on reducing Creative Accounting practices. This means that there is agreement among the respondents that the independent variables have the capacity to reduce CAP. 
Table 4. ANOVA Test. Factor Variable: CAP

\begin{tabular}{|ll|c|c|c|c|c|}
\hline & & $\begin{array}{c}\text { Sum of } \\
\text { Squares }\end{array}$ & df & Mean Square & $\mathrm{F}$ & Sig. \\
\hline CGV & Between Groups & 2.189 & 14 & .156 & .922 & .612 \\
& Within Groups & .509 & 3 & .170 & & \\
& Total & 2.698 & 17 & & & \\
NASB & Between Groups & 1.084 & 6 & .181 & 18.990 & .174 \\
& Within Groups & .010 & 1 & .010 & & \\
& Total & 1.093 & 7 & & & \\
\hline
\end{tabular}

Table 5. OLS Regression Result. Dependent Variable: CAP

\begin{tabular}{|c|c|c|c|c|c|}
\hline & & \multicolumn{2}{|c|}{ Unstandardized Coefficients } & t & Sig. \\
\hline Model & Sign & B & Std. Error & B & Std. Error \\
\hline (Constant) & & 4.952 & 1.639 & $3.023^{\star \star}$ & .029 \\
CGOV & - & -.582 & .363 & -1.603 & .170 \\
NASB & - & -.051 & .432 & -.118 & .911 \\
\hline
\end{tabular}

R-square $=0.345 \quad$ Adj. R-square $=0.083$, F stat $=6.088(0.301)$

\subsection{Test of Hypotheses}

Based on Table 5 above, the OLS result shows that about $34.5 \%$ of the systematic variation in CAP is explained by the two independent variables (CGOV and NASB). This coefficient of determination is poor and does not show a good fit of the regression line as well as indicates that the forecasting power of the model is low. Also, the F value of 6.088 is not statistically significant at 5\%.This means that CGOV and NASB have no significant linear relationship with CAP. The apriori signs are all are negative and correct. This implies a decreasing impact on the Creative Accounting practices, with CGOV having a greater impact. None of the parameters is statistically significant at the $1 \%, 5 \%$ and $10 \%$ levels. That is, for CGOV, the $t$ value of -1.603 is not significant at $5 \%$. Hence hypothesis one is rejected meaning CGOV has no significant impact on Creative Accounting practices in Nigeria. Similarly, the t-value of NASB of -0.118 is less than -1.96 at the $5 \%$ level of significance. Hence we reject hypothesis two that the policing of companies by the NASB will decrease Creative Accounting practices in Nigeria.

\section{Summary of Findings}

This study reveals the following findings:

1. Creative Accounting exists in published financial statement and annual reports of companies in Nigeria and the practice is considered by many of the stakeholders especially the regulatory agencies as bad and meant to deceive or take advantage of users who usually are unable to detect such practices in the financial statements of these companies.

2. Both corporate governance and enforcement and monitoring activities of regulatory agencies are weakly correlated to Creative Accounting practices and they have insignificant impact on creative accounting practices.

3. More often than not, where incidence of creative accounting practices were manifested in the financial statement of companies the auditors were found to be complacent over their responsibilities .

\subsection{Conclusion}

Creative Accounting has some positive manifestations for example income smoothing. However, the negative aspects usually have the tendency to deceive or convey wrong information to users of companies reports such paper profits and deceifful capital structure. Bad corporate governance always takes advantage of the inadequacies or flexibilities in the accounting standards to engage in Creative Accounting practices. Many probabilistic areas such as accounting for price level changes or inflation have no standards. Others like depreciation, stock, revenue recognition, consolidation policy, off-balance sheet items, goodwill, provisions, commitments and contingencies, pension costs and retirement plans etc 
allows alternative accounting and creativity. This gives room for manipulations of accounting information by preparers to the disadvantage of accounting information users especially where there is weak and deficient regulatory mechanism to check these abuses.

\subsection{Recommendations}

1. The fight against corruption in both the public and private sectors in Nigeria must continue and be massively supported by all if this practice is to be arrested.

2. The Nigerian Accounting Standards Board (NASB) must do more in ensuring that companies operating in Nigeria comply with the SAS. She must strengthen her operation towards inspecting, investigating and monitoring companies' compliance. In addition to sanctions for any company and auditors who default in submitting their annual reports or engage in creative accounting practice, NASB should also embark on enlightenment and moral persuasions.

3. Similarly, a concerted effort is needed to reduce the incidence of Creative Accounting in the Nigeria capital markets to restore transparency, integrity, relevance and reliability to financial reports and information so that investors and users (both local and foreign) can have confidence in their usage.

4. NASB should also work in issuing new standards or reviewing existing ones to narrow the gaps or address the grey areas which give rooms for managers to engage in Creative Accounting practices.

5. There is need for heavy sanctioning for any auditor who joins management in such ignoble act, and also to encourage the audit-committee members to more effective performance to curtail the practices in Nigeria. An auditor should not hesitate to qualify the accounts if the company is unable or unwilling to prepare financial statements which give a true and fair view.

6. The strengthening of the code of corporate governance for companies as well as the present effort by the NASB to introducing accounting ethics and values into the training of accountants into the university curriculum should be supported.

7. The accountants should pledge to perform without fear and favour. The corporate management should ensure sound and impartial internal control system and the audit committee should ensure periodic affirmation of corporate code of conduct and increased oversight functions.

\section{References}

Adedipe, B. (2004). Corporate governance: Key factors in financial sector stability. CBN Bullion, 28(1), 55- 57

Alexander, A. \& Archer, S. (2003). On earnings reality, representational faithfulness and true and fair override. Accounting and Business Research, 33(1),3-17

Amat,O, Blake, J. \& Dowds, J. (1991) The ethics of creative accounting. Journal of Economic Literature, December.

Asein, A.A (2004) Carrying the cross of Enron. The Nigerian Accountants, Jan/March, 28-31

Bazerman, M.H., Loewenstein, G \& Moore, D.A. (2002) .Why good accountants do bad audits. Harvard Business Review, 97- 102

Beasley, M.S (1996) .An empirical analysis of the relationship between the board of directors, composition and financial statement fraud; The Accounting Review, 71, 443-465

Beidlamen, C.R (1973) .Income smoothing: the role of management; The Accounting Review.October,pp 658-667

Black,E.L.,Sellers, K..F \& Manly, T.S (1998). Creative accounting using asset sales: An international studies of countries allowing noncurrent assets revaluation. Journal of Business Finance and Accounting 25(9) 1287-1317

Breton, G. \& Taffler, R.J. (1995) .Creative accounting and investment analyst response; Accounting and Business Research , 25(98), 81-92

Carlson, S.J. \& Bathala, C.T (1997). Ownership differences and firms income smoothing behaviour. Journal of Business Finance and Accounting , 24, 179-196

Davidson,J. (2002). Communication and antithesis in corporate annual reports; A research note $h$ ttp:www/brunnel.ac.uk/66/efwps/02/13

Dechow, P.W \& Skinner, D.J. (2000) Creative accounting: Reconciling the views of accounting academics, practitioners and regulators; Accounting Horizon, 14 (2), 235-251

Defond, M.L \& Park, C.W. (1998) . Smoothing income in anticipation of future earnings. Journal of Accounting and Economics, 23, 115139

Demski, J. (1994). Managerial uses of accounting information. Kluwer, Boston

Dey, A (2004) Income smoothing and sophisticated investors' preference; Kellog school of management North Western University; Sept.

Donnelly, R \& Lynch, C. (2002). The ownership structure of UK firms and the informativeness of accounting earnings; Accounting and Business Research 32(4) , 245-257

Elliot, B \& Elliot, J. (2004). Financial accounting and reporting. (8th ed. ). Harlow Prentice Hall and Financial Times. 
Fox,J. (1997) Learning to play the earnings game ;Fortune 31 July pp56

Gillespines,I. \& Lewis, R. (2000). Principles of financial accounting ;Financial Times /Prentice

Giroux, G. (2004). Detecting earnings management; Hoboken NJ John Wiley \& Son Inc

Giroux, G. (2006) . Earnings magic and the unbalance sheet: The search for financial reality. New Jersey, NJ John Wiley \& Son Inc

Gramlich ,J.D., McAnally , M.L \& Thomas, J. (2001). Balance sheet management: The case of short-term obligations reclassified as long-term debt. Journal of Accounting Research, 39(2) , 283-295

Griffin,I.I(1995) .New creative accounting :How to make you're your profits what you want them to be . London Macmillan

Griffin,I.I.(1995). Creative accounting, London, Sidgwick and Jackson

Healy,P.M. (1985). The effect of Bonus Scheme on accounting decisions. Journal of Accounting and Economics 7, 85-107

Heyworth, S.R. (1953) :Smoothing periodic income. The Accounting Review, January 32-39.

Healy,P.M \&.Wahlen, J.M (1999). A review of the creative accounting literatures and its implication for standards setting. Accounting Horizons, 4, 365-383

Hillier, J \& McCrae, M. (1998). The earnings smoothing potential of systematic depreciation. Abacus ,34(1) , 75-91

Hermann, \&.Inoue, T. (1996). Income smoothing and incentives by operation condition: An empirical test using depreciation changes in Japan. Journal of International Accounting, Auditing and Taxation ,15,161-178

Kinney, W.R Jr \& McDaniel, L.S. (1998) . Characteristics of firms correcting previous reported quarterly earnings; Journal of Accounting and Economics11 Feb, 71-93

Idialu, J.U. (2004). Depreciation practices of quoted companies in Nigeria. The Nigerian Accountant July/Sept, 55-60

Imhoff, E.A.(2003). Accounting, auditing and corporate governance. Accounting Horizon Supplement 17

Jensen, M.C.\& Meckling, W.H. (1976). Theory of the firm: Managerial behavior, agency costs and ownership structure in M. C. Jensen (Eds.) A theory of the firm: Governance, residual claims and organizational forms, Harvard University Press

Largay, J. (2002). Lessons from Enron. Accounting Horizons, 16 (2), 154

Levitt, A (1998). The number game note http:www.Sec.gov.news/speeches/spch220.Ext

Liandu, N (2004). Earnings management-why worry about it? http:www.accaglobal/publications/studentaccounting /121030206

Merchant, K.A \& Rockiness , J. (1994). The ethics of managing earnings: An empirical investigation. Journal of Accounting \& Public Policy, 13, 79-94

Moses,O.D . (1987). Income smoothing and incentives: Empirical tests using accounting changes. The Accounting review, 62(2) , 356377

NASB (2005). One-day consultative forum for key players and regulators in the Nigerian capital market;. Sheraton Hotel,Lagos.15 th Sept,2005.

McNichols, M. \& Wilson ,G.P.(1988 ). Evidence of creative accounting from the provision for bad debts. Journal of Accounting Research, 26 (Supplement) 1-33;

Naser, K. (1993). Creative financial accounting: Its nature and uses; Itemel Hempstead Prentice Hall.

Nelson,M.N., Elliot, J.A \& Tarpley, R.L. (2002). Evidence from auditors about managers and auditors earnings management decisions

Niskanen,J \& .Keloharju, M . (2000): Earnings cosmetics in a tax driven accounting environment: Evidence from Finish public firms. The European Accounting Review , 19 (3) , 443-452

Obazee, J.O. (2005): The inspectorate unit guidelines: bridging the expectation gap. Paper presented at the One day consultative forum for key players and regulators in the Nigerian capital market organized by NASB; Sheraton Hotel,Lagos. 15th Sept, 2005.

Odia,J.O. (2005). Creative accounting and its implications for corporate financial reporting in Nigeria. Unpublished Msc.Thesis, University of Benin, Nigeria.

OECD (2004): OECD principles of corporate governance, available at www.oecd.org

Okeahalam C.C \& Akinboade, O. A. (2003). A review of corporate governance in Africa : Literature, issues and challenges. Paper presented at the Global Corporate Governance Forum, June,2003.

Okoye, E.J \& Alao, B.B. (2008). The ethics of creative accounting in financial reporting: The challenges of regulatory agencies in Nigeria. Certified National Accountant, 16(1), January - March ,45-54

Oladimeji, A (2003) . Issues in Corporate Governance. Financial Institution Training Centre, Lagos.

Oladimeji, A (2007). Corporate Governance in Nigeria ; An Overview. CBN Bullion 31(3)(July/Sept), 1-6

Osaze,B.E ('1998) .Creative accounting :Poison or positive ingenuity. The Nigerian Accountant July/Sept , 32-35

Palmrose,Z-V.r Vernon, J.\& Scholz.S.W. (2004). Determinant of market reaction to earnmings restatement announcements. Journal of Accounting Economics, 37(1)

Peasnell,K.V (2001) :Board monitoring and earnings management:Do outside directors influence abnormal accrual. Working Paper, Lancaster University.

Revine,L., Collins, D \& Johnson,B. (2005). Financial reporting and analysis . Pearson/ Prentice Hall.

Riahi-Belkaoui, A (2000). Accounting theory. London, Thomson Learning

Sack (2004). Fraud risk: Are you prepared; Journal of Accounting, Sept, 51-63

Schipper,K (1989). Commentary on creative accounting. Accounting Horizon December , 91-102

Schiff, David (1993). The dangers of creative accounting. Worth (March) , 92-94.

Spohr,J.(2004).Testing for Income using discretionary accrual. http://www.heer.fi/FDPE/document/capital /capital_js.paper.pdf

Sutton .(2000). Corporate financial accounting and Reporting . Financial times/Prentice Hall 
Sweeney, H.W (1994) . Debt covenant, violations and managers accounting responses. Journal of Accounting and Economics , 17, 251308

Talib,N.A.(2003): An empirical analysis :Audit committee structure and association with earnings management Masters Thesis/Dissertation UITM

Vladu, A.B and Matis, D. (2010): Corporate governance and creative accounting: Two concepts strongly connected? Some interesting insights highlighted by constructing the internal history of a literature. Annales Universitatis Apulensis Series Oeconomica, 12(1), 332-346

Wu,Min (2002): Restatement . Unpublished dissertation New York University. 